\title{
Pyoderma Vegetans - a Case Report
}

\author{
Ljubica JEVREMOVIĆ ${ }^{1 *}$, Ivana ILIJIN¹, Kristina KOSTIĆ1, Željko MIJUŠKOVIĆ1, \\ Ivana TUFEGDŽIĆ ${ }^{2}$ and Lidija KANDOLF SEKULOVIĆ ${ }^{1}$
}

${ }^{1}$ Department of Dermatology and Venereology, Military Medical Academy, Belgrade, Serbia

${ }^{2}$ Institute of Pathology and Forensic Medicine, Military Medical Academy, Belgrade, Serbia

*Correspondence: Ljubica Jevremović, E-mail: ljubicajevremovic@hotmail.com

UDC 616.5-002.3/.4:616.981.2]-08

\begin{abstract}
Pyoderma vegetans (PV) or blastomycosis-like pyoderma (BLP) is a chronic inflammatory disease, by some authors considered a rare variety of pyoderma gangrenosum (PG), and others describe it as a distinct entity. It commonly presents with verrucous plaques with multiple pustules. The etiology of this disease is unknown, but it has been connected with staphylococcal and streptococcal infections, inflammatory bowel disease, hematological diseases, primary immunodeficiency, alcoholism, and nutritional deficit. Here we present a 66-year-old, otherwise healthy female, with a 2-year-long history of well-defined, vegetative livid plaques with multiple pustules on the dorsal side of both hands. Histopathological analysis of the skin biopsy of the hand showed chronic inflammation and microabscesses, ruptured follicular cysts and follicular pseudoepitheliomatous hyperplasia. Treatment with anti-tuberculosis drugs and antibiotics showed to be ineffective, as well as the treatment with systemic corticosteroids, dapsone and cyclosporine. Itraconazole was given for its immunomodulatory effects and findings of Penicillium species in one of the swabs, which led to partial regression of lesions. Since the treatment did not lead to complete resolution, acitretin was indicated 3 months later, but the patient was lost to follow-up.
\end{abstract}

Key words: Pyoderma; Blastomycosis; Hand Dermatoses; Cyclosporine; Dapsone; Itraconazole; Treatment Outcome; Case Reports

Pyoderma vegetans (PV) or blastomycosis-like pyoderma (BLP) was first described by Hallopeau in 1898, under the name of "pyodermite végétante", and five years later, in 1903, by Azua and Pons as "pseudo-epitheliomatous cutane". Commonly used synonyms for this disease include pyodermitis chronica vegetans of Azua, pseudoepithelioma of Azua, mycosislike pyoderma, coral reef granuloma (in Australia), and hyperinflammatory proliferative pyoderma $(1,2,3)$.

It is characterized by exudative, verrucous plaques with well-defined elevated borders and multiple pustules (4). Although its etiology is unknown, this disease has been connected to bacterial infections (staphylococcal and streptococcal). Fungal infections have also been implicated in the context of immunosuppression, as demonstrated by a case of treatment-resistant Trichophyton mentagrophytes-induced infection of the hands, resulting in a chronic pyoderma vegetans (5). Other diseases that might be associated with this condition include inflammatory bowel dis- ease, cutaneous T-cell lymphoma, primary immunodeficiency, chronic myeloid leukemia, alcoholism, HIV infection and nutritional deficit. However, it has also been reported in healthy persons $(4,6)$. Major histopathological features of PV are pseudoepitheliomatous hyperplasia and intraepidermal and subepidermal neutrophilic or eosinophilic micro-abscesses (1). In most cases this disease has a chronic course and it is often refractory to antibiotic therapy (1, 7). No standard treatment guidelines are available for PV, maybe because of its rarity.

Here, we present a case of PV in an otherwise healthy adult female, and a short review of literature on the treatment challenges of this rare disorder.

\section{Case report}

A 66-year old female was referred to our clinic with a 2-year history of well-defined erythematous livid plaques, with mild desquamation and pustules on erythematous base, lo- 
cated on the dorsum of the right hand, measuring $5 \times 5 \mathrm{~cm}$. Also, similar plaque characteristics, measuring $3 \times 3 \mathrm{~cm}$, were found on the IV and $\mathrm{V}$ fingers on the dorsal side of the left hand. There was a non-healing lesion, 1 $\mathrm{cm}$ in diameter, covered with a crust, on the skin of the left knee (Figure 1).

The patient was previously treated as an out-patient with topical and systemic corticosteroids and systemic antibiotic therapy based on culture, but without favourable results. In April 2015, Mantoux test was performed and it was positive, with erythema and induration $30 \mathrm{~mm}$ in diameter, the patient received therapy with isoniazid, rifampicin, ethambutol and pyrazinamide during two months, but without effects. Tissue cultures for typical and atypical mycobacteria were negative and therapy was discontinued. She was otherwise healthy, except for the hypertension treated for several years with combination antihypertensive therapy (enalapril maleate, bisoprolol, acetylsalicylic acid and amlodipine).

Laboratory test results revealed elevated erythrocyte sedimentation rate of 44 $\mathrm{mm} / \mathrm{h}$; fibrinogen $5.6 \mathrm{~g} / \mathrm{L}(<4)$ and C-reactive protein $9.86 \mathrm{mg} / \mathrm{l}(<4)$; immunoglobulin E 171 $\mathrm{IU} / \mathrm{ml}(<100)$; free triiodothyronine (FT3) $12.62 \mathrm{pmol} / \mathrm{l}(<6.5)$. All other findings were within normal limits including the following: complete blood count, kidney, liver function tests and serum electrolyte levels, rheumatoid factor, lipid status, immunoglobulins (A, G, $\mathrm{M})$, complement factor $\mathrm{C} 3$ and $\mathrm{C} 4$, angiotensin converting enzyme, free thyroxin, thyroid stimulating hormone (TSH), anti-thyroid peroxidase antibodies, thyroglobulin antibodies, TSH receptor antibodies, serum protein electrophoresis and complete urinalysis. VDRL/TPHA, Anti-HIV antibodies, HBsAg, and anti-HCV were negative. Bacteriological cultivation was repeatedly positive for Staphylococcus aureus. Skin biopsy tissue mycological cultivation was negative as well as cultivations for typical and atypical mycobacteria. Further diagnostic work-up did not reveal hematologic malignancy (peripheral blood smear), inflammatory bowel disease (with colonoscopy), connective tissue diseases (ANA, ENAA, ANCA, circulating immune complexes, RF) and paraneoplastic process was also excluded. Also, patch testing to standard allergens of the European series was negative.

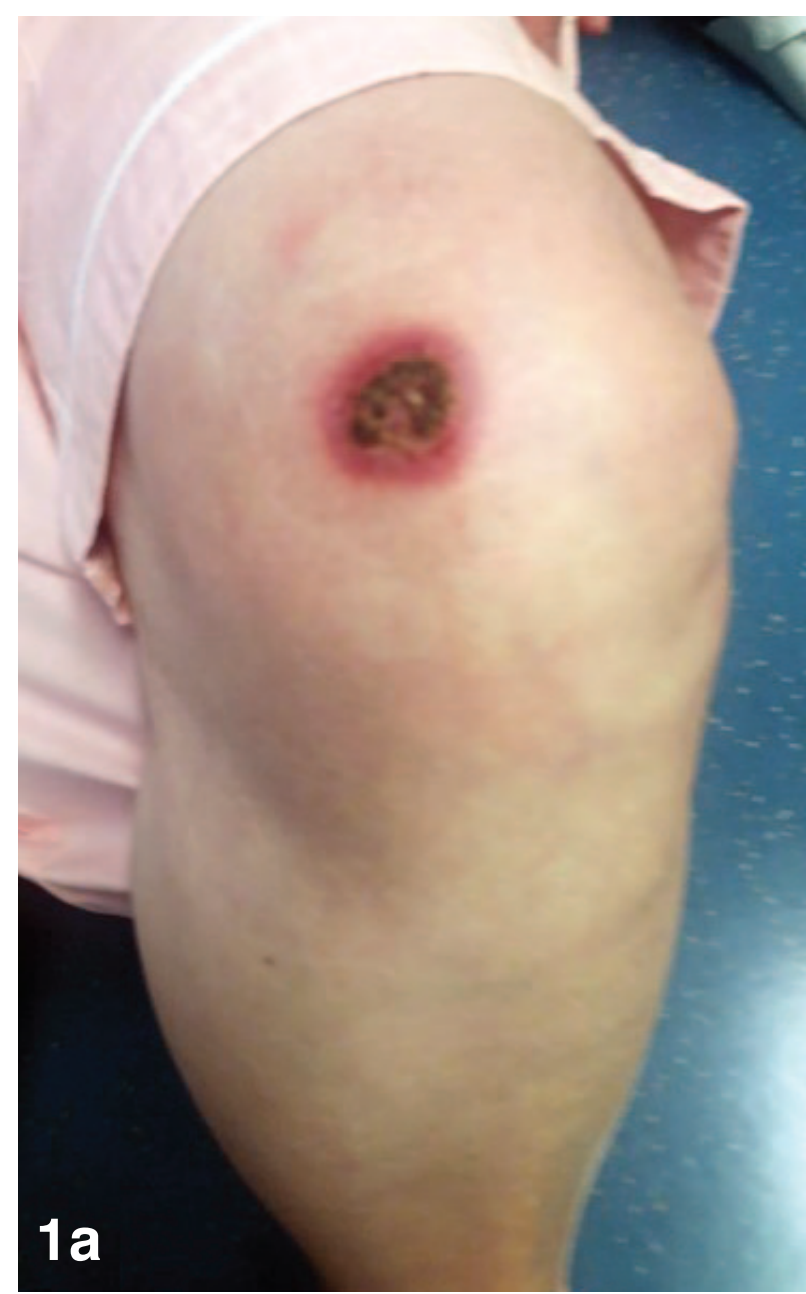

Figure 1 a. A non-healing lesion, $1 \mathrm{~cm}$ in diameter, covered with crust, on the left knee

Histopathological analysis of skin biopsy specimens showed chronic inflammation and cutaneous micro-abscesses, ruptured follicular cysts and follicular pseudoepitheliomatous hyperplasia (Figure 2). Periodic acid Schiff (PAS) and the Ziehl-Neelsen staining did not show presence of microorganisms in biopsy specimens. Repeated biopsies revealed pseudo-epitheliomatous hyperplasia and formation of micro-abscesses. Direct immunofluorescence microscopy did not show deposits of immunoreactants in the basement membrane zone.

Based on clinical and histopathological findings, the patient was diagnosed with vegetans form of pyoderma gangrenosum and treatment was initiated with methylprednisolone $40 \mathrm{mg} /$ day and dapsone $100 \mathrm{mg} /$ day (due 


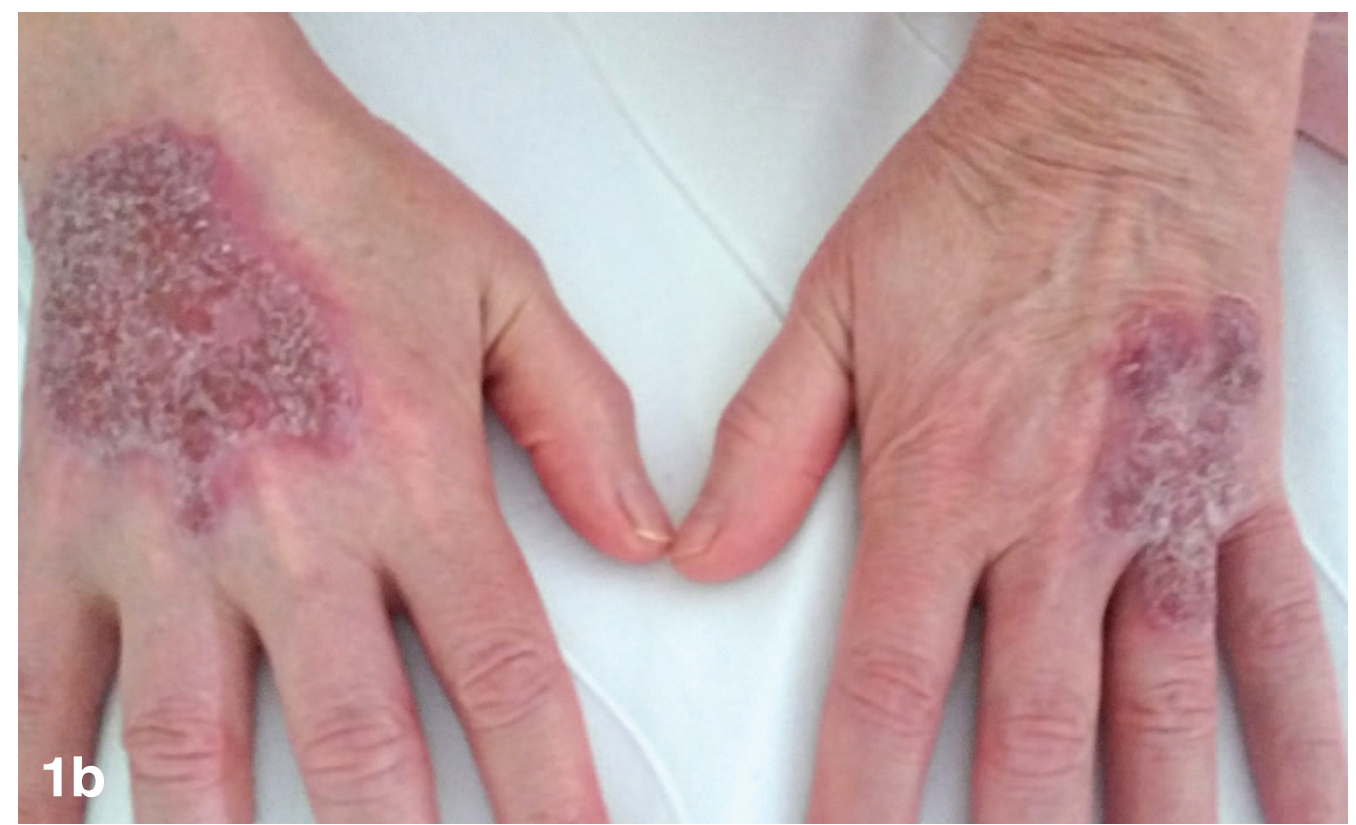

Figure 1 b. Erythematous livid plaques on the dorsal side of the hands

to methemohlobinemia, the dose was reduced to $50 \mathrm{mg} /$ day after 2 weeks). Topical betamethasone dipropionate $0.5 \mathrm{mg} / \mathrm{g}$ ointment was used twice a day during two months, then pimecrolimus $1 \%$ cream for one month. Also, on two occasions, 6 weeks apart, intralesional triamcinolone-acetonide was applied. Three months after the initial treatment, skin lesions deteriorated, with spreading of erythematous-violaceous plaques on the skin of both dorsal aspects of hands and the left knee. Since the initial treatment proved ineffective, it was discontinued and cyclosporine was used ( $5 \mathrm{mg} / \mathrm{kg}$ ), but it was also ineffective and discontinued after one month. After that, the patient was treated with amoxicillin and clavulanic acid tablets for 10 days (625 mg $3 \times 1$ ), based on findings of Staphylococcus aureus, but again without improvement.

Saprophytic Penicillium species were found in one of the repeated fungal cultures. Having in mind the possible role of saprophytic mould in chronic inflammation, immunomodulatory properties of itraconazole and one case report of effective treatment of pyoderma vegetans using this drug, treatment with itraconazole was initiated at a dose of $400 \mathrm{mg} /$ day for 7 days followed by a 3-week break for 2 months, with initial regression, after which the treatment was continued with itraconazole $100 \mathrm{mg} /$ day for another month. During treatment, liver function tests were within the physiological range. Topical miconazole $2 \%$ cream was applied twice a day for one month. Skin lesions showed significant regression in terms of their size, infiltration and erythema (Figures $3 \mathrm{a}$ and $3 \mathrm{~b}$ ). However, since the treatment did not lead to complete resolution of the lesions, acitretin was indicated 3 months later, but the patient was lost to follow-up.

\section{Discussion}

Pyoderma vegetans, also named blastomycosis-like pyoderma, is a very rare disease. There is no actual data about the incidence of this disease. The largest case series was reported by Scuderi et al. in 2016. They described 39 patients collected over a 35-year period to demonstrate its clinical features and histological findings. Of the 39 cases, 29 $(74 \%)$ were men. The average age was 71 ; the youngest patient was 44 and the oldest 91 years old. In all 39 cases, the most common site was the forearm in 25 (64\%) cases. Three patients had multiple lesions at clinical presentation (8). Our patient also belongs to elderly population with more than one lesion.

Pyoderma vegetans is believed to represent a vegetating inflammatory tissue reaction 
to a bacterial infection, generally occurring in patients with reduced immunological resistance or in immunosuppressed patients. It has been reported in association with HIV infection/AIDS, hematologic and solid malignancies, malnutrition, alcoholism, diabetes mellitus, obesity, inflammatory bowel diseases, psoriatic arthritis, pulmonary granuloma, immunosuppressive therapies, X-radiation, and other conditions $(2,3,5$ - 11). However, several cases of PV were described in immunocompetent patients without any underlying factors $(1,2,7)$. Minor trauma may be the trigger factor for the beginning of lesions, probably creating a localized area of impaired resistance $(2,8)$. In Australia, a variant of PV has been reported under the term of coral reef granuloma, which typically occurs on sundamaged skin of elderly patients $(2,12)$. In our patient, no underlying disease was diagnosed after a thorough follow-up, but it did develop on sun-damaged areas.

The diagnosis of BLP is based on clinical, pathological, and laboratory findings. Su et al. proposed five diagnostic criteria for this disease in 1979: 1) large verrucous plaques with multiple pustules and elevated border, 2) pseudoepitheliomatous hyperplasia with abscesses in tissue biopsy, 3) growth of at least one pathogenic bacterium, 4) negative culture for deep fungi, atypical mycobacteria or mycobacterium tuberculosis, and 5) normal bromide levels (1). In 2005, Nguyen at al. adopted these criteria and added another one negative fungal serological tests (2). Our pa- tient fulfilled four of the six criteria, but fungal serology tests were not performed and halogen blood levels were not measured due to negative history of using medications containing halogens.

The differential diagnosis of PV should include pemphigus vegetans, deep fungal infections, verrucous cutaneous tuberculosis, skin infections caused by mycobacterium marinum, squamous cell carcinoma, pyoderma gangrenosum, keratoacanthoma, cutaneous botryomycosis, halogenoderma and insect bites $(2,12)$. We excluded these conditions in our patient by evaluation of skin lesions, negative mycobacterium tuberculosis culture and by negative direct immunofluorescence test. Also, the 2-month course of anti-tuberculosis therapy was ineffective, as it proved to be effective in vegetative pyoderma gangrenosum.

Various modalities have been used in the management of PV. Currently there is no guide to treatment, but systemic corticosteroids are usually the first choice. Doses of 1 $\mathrm{mg} / \mathrm{kg} /$ day were reported to be successful to control the inflammation and relieve pain in some cases. This dose should be continued until the lesions show evidence of healing and then, gradually decreased. A steroid-sparing agent, such as minocycline, dapsone, rifampicin, vancomycin or clofazimine may be added $(6,7)$. However, these treatment modalities were found to be completely ineffective in our patient. Systemic antibiotics have been used, including minocycline, penicillin

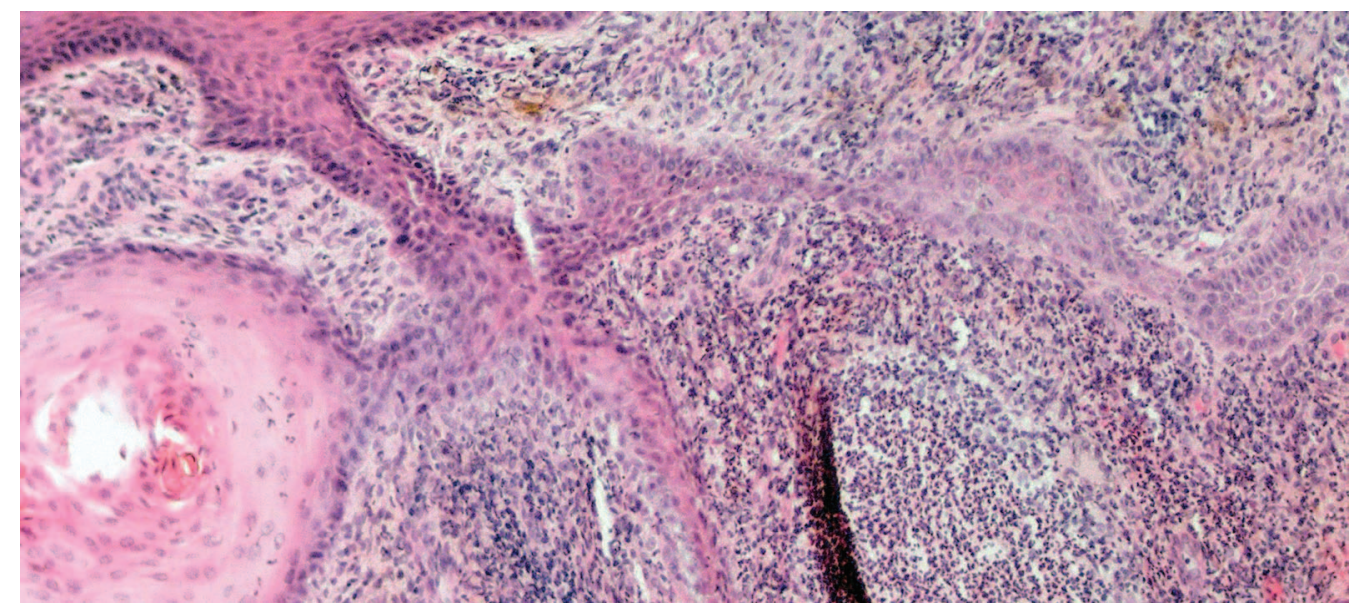

Figure 2. Microscopic features of skin biopsy specimen, with cutaneous microabscesses, ruptured follicular cysts, and follicular pseudo-epitheliomatous hyperplasia (Hematoxylin and eosin, 40x) 

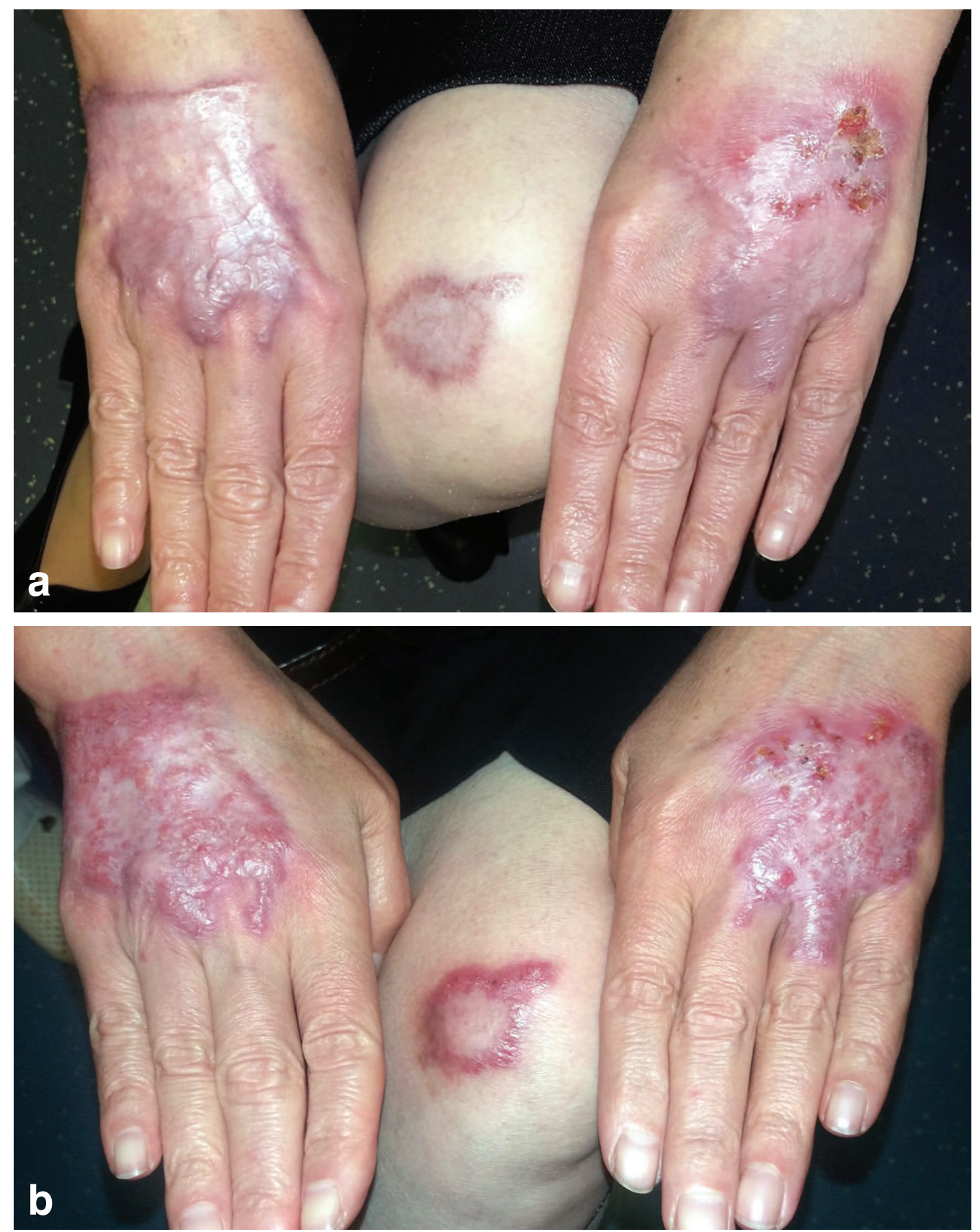

Figures 3a. October 2016. Plaques on the dorsal side of the hands and left knee three weeks after thepary with itraconazole; 3b. March 2017. Plaques on the dorsal side of the hands and left knee 6 months after initiation of itraconazole

and ciprofloxacin (8). Physical therapies, such as curettage and a carbon dioxide laser, have also been successfully employed in one case report (13). Recently, a few authors described good response with the use of acitretin. Case reports demonstrate a response to doses ranging from 10 to $37.5 \mathrm{mg} / \mathrm{per} /$ day of acitretin for a variable duration, the longest being 8 months $(2,8,12,14)$. Coulombe J. et al. also successfully treated one patient with PV in association with Candida albicans using itraconazole (3). An analogy between chronic 
vegetating pyoderma and recalcitrant tinea is yet to be discussed (9). Carrera et al. reported a patient with pyoderma associated with psoriasis that was successfully treated with tumor necrosis factor inhibitor etanercept (5).

In our patient, itraconazole led to partial regression of lesions, possibly due to its immunomodulatory properties. In a review of the immunomodulatory activity of antifungal drugs, Yamaguchi et al. suggested that azoles, in general, not just itraconazole, tend to act as immunosuppressants (15). Naranjo et al. investigated itraconazole activity on lung levels of certain cytokines both anti-inflammatory (IL-13, TGF- $\beta$ ) and pro-inflammatory (IL-1 $\beta$, TNF- $\alpha$, IFN- $\gamma$ ) and PGE2, in healthy and Paracoccidioides brasiliensis infected mice and showed that levels of IL- $1 \beta$ and IL- $1 \alpha$ were decreased significantly in the lungs of treated mice; these cytokines are considered important molecules in antifungal host defences and key to induction of the Th1 protective response and showed that pulmonary levels of IL-4, IL-10, and IL-13, considered anti-inflammatory molecules, were higher during and even 4 weeks after the end of ITC treatment in mice (16). However, in our patient complete regression was not achieved and the treatment with acitretin was considered, but the patient refused this treatment option and was lost to follow-up.

Further studies regarding the treatment duration and efficacy are necessary to determine which modalities are the most successful and timely.

\section{Conclusion}

There are no clinically controlled trials examining the efficacy of different treatment regimens for pyoderma vegetans, or blastomycosis-like pyoderma. Previous reports and small case series showed that response to therapy is variable or poor, whereas the course of the disease is often long and frustrating for both patients and physicians. Our patient showed significant improvement after administration of itraconazole, with significant regression. Based on individual case reports, the treatment with acitretin should also be considered in this treatment resistant disease.

\section{Abbreviations}

PG - Pyoderma gangrenosum

PV - Pyoderma vegetans

BLP - Blastomycosis like pyoderma

HIV - Human Immunodeficiency Virus

VDRL/TPHA - Venereal disease research laboratory/Treponema pallidum hemagglutination assay

TSH - Thyroid stimulating hormone

HBsAg - Hepatitis B surface antigen

anti-HCVAt - Antibodies for hepatitis $C$ virus ANA - Antinuclear antibody

ENAA - Extractable Nuclear Antigen Antibodies

ANCA - Anti-neutrophil cytoplasmic antibodies

RF - Rheumatoid factor

IL-13 - Interleukin-13

TGF- $\beta$ - Transforming Growth Factor-Beta

IL-1 $\beta$ - Interleukin-1 Beta

TNF- $\alpha$ - Tumor necrosis factor-alpha

IFN- $\gamma$ - Interferon gamma

PGE2 - Prostaglandin E2

IL-1 $\alpha$ - Interleukin-1 alpha

IL-4 - Interleukin-4

IL-10 - Interleukin-10

\section{References}

1. Su WP, Duncan SC, Perry HO. Blastomycosis-like pyoderma. Arch Dermatol. 1979;115(2):170-3.

2. Nguyen RT, Beardmore GL. Blastomycosis-like pyoderma: successful treatment with low-dose acitretin. Australas J Dermatol. 2005;46(2):97-100.

3. Coulombe J, Bertrand J, Lavoie M, Lessard M, Leclerc G, Dupéré A. Pyoderma vegetans due to Candida albicans: successful treatment with itraconazole. Ann Dermatol Venereol. 2012;139(12):836-7.

4. Schroder M, Perez Search GC, Sorin Search I, Mazzuoccolo L. Pyoderma gangrenosum vegetans. J Clin Case Rep. 2015;5(11):645-6.

5. Carrera C, Mascaró JM Jr, Moreno-Romero JA, Iranzo P, Palou J, Zamora E, et al. Pyoderma vegetans associated with severe psoriatic arthritis: good response to etanercept. Dermatology. 2007;214(1):77-81.

6. Canpolat F, Cemil BÇ, Yilmazer D, Yesilli O, Eskioglu F. Pyoderma vegetans associated with ulcerative colitis: a case with good response to steroids. Case Rep Dermatol. 2011;3(1):80-4. 
7. Wollina U. Pyoderma gangrenosum - a review. Orphanet J Rare Dis. 2007;2:19.

8. Scuderi S, O'Brien B, Robertson I, Weedon D. Heterogeneity of blastomycosis-like pyoderma: a selection of cases from the last 35 years. Australas J Dermatol. 2017;58(2):139-41.

9. Skorepova M, Stuchlik D. Chronic pyoderma vegetans triggered by Trichophyton mentagrophytes. Mycoses. 2006;49(2):143-4.

10. Kobraei KB, Wesson SK. Blastomycosis-like pyoderma: response to systemic retinoid therapy. Int J Dermatol. 2010;49(11):1336-8.

11. Mansouri M, Rakhshan A, Shahidi-Dadras M, Karimi A, Alavi S. Pyoderma vegetans: a case report in a child suspected to primary immunodeficiency and review of the literature. Iran J Med Sci. 2015;40(4):381-5.

12. Cecchi R, Bartoli L, Brunetti L, Pavesi M. Blastomycosis-like pyoderma in association with recurrent ve- sicular hand eczema: good response to acitretin. Dermatol Online J. 2011;17(3):9.

13. Sawchuk WS, Heald PW. Blastomycosis-like pyoderma - report of a case responsive to combination therapy utilizing minocycline and carbon dioxide laser debridement. J Dermatol Surg Oncol. 1986;12(10):1041-4.

14. Lu XL, Zhao W, Xia YK, Chen J, Wang L, Zhou XW, et al. Good response of a combined treatment of acitretin and antibiotics in blastomycosis-like pyoderma. Eur J Dermatol. 2009;19(3):261-2.

15. Yamaguchi $\mathrm{H}$, Abe S, Tokuda Y. Immunomodulating activity of antifungal drugs. Ann N Y Acad Sci. 1993;685:447-57.

16. Naranjo TW, Lopera D, Zuluaga AF, Cano LE. Immunomodulatory activity of itraconazole in lung. Tropical Journal of Pharmaceutical Research. 2016;15(12):2603-9.

\section{Pyoderma vegetans - prikaz slučaja}

\section{Sažetak}

Pioderma vegetans (Pyoderma vegetans - PV) ili blastomukoza nalik piodermi (Blastomycosis-like pyoderma - BLP) hronično je inflamatorno oboljenje koje pojedini autori smatraju retkim oblikom pioderme gangrenozum (Pyoderma gangrenosum - PG) dok je drugi opisuju kao poseban entitet. Za ovo oboljenje najčešće je karakteristično prisustvo verukoznih plakova sa multitplim pustulama. Etiologija ovog oboljenja je nepoznata, mada je povezivana sa infekcijom stafilokokom i streptokokom, inflamatornim bolestima creva, hematološkim malignitetima, primarnim imunodeficijencijama, alkoholizmom i malnutricijom. Ovde opisujemo slučaj PV kod 66-godišnje ženske osobe, bez udruženih bolesti, kod koje su jasno ograničeni vegetativni lividni plakovi sa pustulama na dorzalnim stranama obe šake bili prisutni unazad dve godine. Histopatološka analiza bioptata kože šaka ukazala je na hroničnu inflamaciju i mikroapscese, rupturirane folikularne ciste i folikularnu pseudoepiteliomatoznu hiperplaziju. Lečenje antituberkuloticima i antibioticima u drugoj ustanovi bilo je bez efekta, a u našoj ustanovi je sprovođena sistemskim kortikosteroidima, dapsonom i ciklosporinom takođe bez odgovora. Itrakonazol je dat zbog svoje imunomodulatorne aktivnosti i nalaza gljivice iz roda Penicillium što je rezultiralo parcijalnom regresijom lezija, ali ne i potpunom regresijom, te je predložena i terapija acitretinom, ali je kontakt sa pacijentkinjom izgubljen.

Ključne reči: Pioderma; Blastomikoza; Dermatoze šaka; Ciklosporin; Dapson; Itrakonazol; Ishod terapije; Prikazi slučajeva 